\title{
GEOLOGIC MAPS OF THE SOUTHWESTERN PUERTO RICO PARGUERA TO GUÁNICA INSULAR SHELF
}

\author{
By Jack Morelock, Elizabeth A. Winget, and Carlos Goenaga
}

\section{INTRODUCTION}

These maps describe the sediments and sedimentary environment of the southwestern Puerto Rico shelf (index). In addition to presenting new data, the maps summarize earlier geological investigations.

There are two morphological zones separated along a line extending southward from Punta Jorobado. The Parguera shelf extends from this line to the western boundary of the study area, and the Guánica shelf extends from Punta Jorobado to the eastern study limit (fig. 1). The age and character of the underlying limestone bedrock, the depositional environment, the history of subaerial erosion, and the intensity of modern physical processes differ in each of these shelf areas. However, the bedrock surface of both the Parquera and Guánica shelves is primarily karst; the limestone surface was modified by reef growth and sediment deposition after the last glacial lowstand. Although several anticlines and faults that trend parallel to the shoreline have been mapped on the adjacent land areas
(Volckmann, 1984), no evidence was found to suggest major structural features on the shelf.

\section{PREVIOUS WORK}

Almy (1965), Grossman (1963), and Volckmann (1984) mapped the land geology adjacent to the Parguera-Guánica insular shelf, and Trumbull and Garrison (1973) and Trumbull (1981) described the insular slope south of the area. Schneidermann and others (1976) and Morelock and others (1977) described the general sedimentary patterns in the study area. Quinn (1972), Saunders (1973), Sawyer (1980), and Morelock and Mathews (1982) studied the sediments in portions of the shelf, and Grove and Trumbull (1978) mapped carbonate sand deposits west of the Parguera quadrangle. Del Valle (1981) investigated the sediments at three sites in Bahía de Guánica, and Morelock and Hernandez (1982) mapped the bottom sediments and current patterns in Bahía de Guánica.

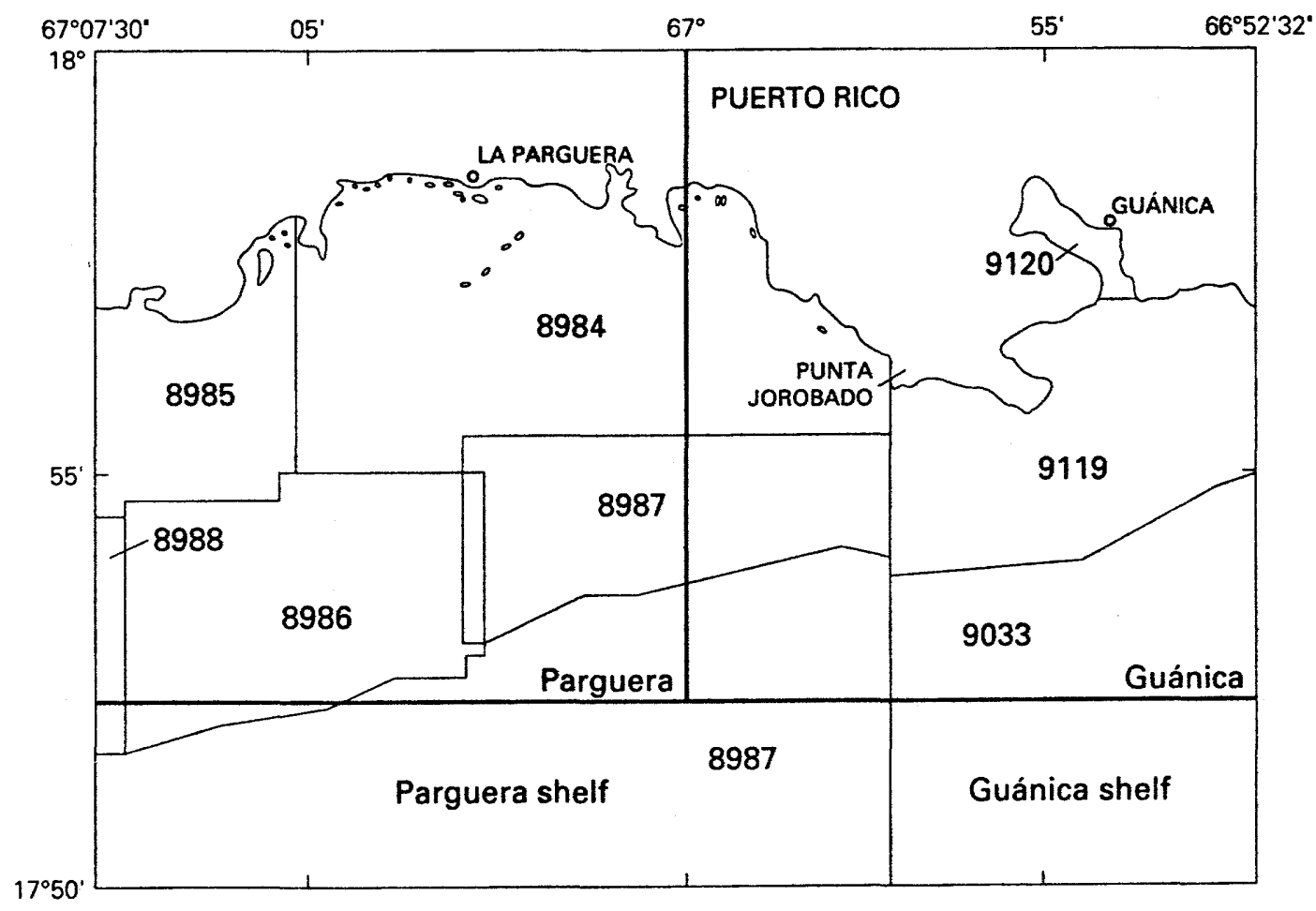

Figure 1.-Location of numbered National Oceanic and Atmospheric Administration-National Ocean Service (NOAA-NOS) bathymetric survey maps and U.S. Geological Survey Parguera and Guánica topographic maps (1966), Puerto Rico. All maps at scale of 1:20,000. 
Morelock and others (1979), Acevedo and others (1989), and Almy and Carrion-Torres (1963) provided a general description of the reefs at Parguera. Several biological investigations include descriptions of individual reef areas: Rogers (1977), Glynn (1973), Boulon (1980), Armstrong (1981), and Matta (1981).

\section{BATHYMETRY}

Bathymetry (fig. 2) is mapped at 2-meter intervals using data from NOAA-NOS charts (fig. 1). The Parguera insular shelf forms a distinct unit. The modem bathymetry and sediment patterns are different east and west of this area, and the morphology of the Pleistocene erosional surface here differs from that of the Guánica area. More than 10,000 years ago, when sea level was lower and the limestone surface of the Parguera shelf was exposed to subaerial erosion, a karst surface developed.

The average water depth of the Parguera shelf is 18 to $20 \mathrm{~m}$, but the depth increases slightly on the western outer shelf. The shelf width varies from 6 to $10 \mathrm{~km}$. The Parguera shelf can be divided into three areas according to wave-energy environments: an outer shelf, a middle shelf, and an inner shelf (Morelock and others, 1977). Both the outer and middle shelves are 18 to $20 \mathrm{~m}$ deep; the inner shelf is a shallow, lagoonlike area less than $6 \mathrm{~m}$ deep. A terracelike band of reefs separates the inner and middle shelf areas (fig. 2).

The middle shelf is characterized by irregular and complex physiography. Submerged reefs, which lie within 4 to $10 \mathrm{~m}$ of the water surface, and more than 15 emergent reefs, which break the surface and have a reef crest, are present. The easterly alignment of reefs between the middle and outer shelves provides a wavereducing baffle that decreases the wave energy reaching the middle shelf.

The outer shelf has an irregular bathymetry, caused by the karst bedrock surface on which there was subsequent reef growth and sediment deposition. All of the outer shelf patch reefs and the submerged shelf-edge reef that collectively mark the shelf margin have tops that are below $8 \mathrm{~m}$ of water depth. Bottom relief has been modified by carbonate deposition. The outer shelf has two broad depressions: the Turromote basin, an erosional feature of a lower sea level that has only been partially filled by sediment, and the Margarita basin, which is part of the general deepening of the shelf toward the west. It also contains Turromote ridge, which is a submerged topographic high between the basin and the reef line.

The insular shelf edge in the Parguera area is marked by an almost continuous, submerged reef that forms a double ridge along most of its length. Similar double and single reef ridges have been described at Ponce, P.R. (Beach, 1975) and in the Lesser Antilles (Macintyre, 1972). The inner ridge is a platform surface 14 to $18 \mathrm{~m}$ below sea level; the narrower outer ridge crests at 16 to $22 \mathrm{~m}$ below sea level. The valley between the ridges ranges from 20 to $35 \mathrm{~m}$ deep and has a relief of 4 to $15 \mathrm{~m}$; the valley deepens westward. The cause, development, and age of the double reef system are not known, but it is clear that this submerged coral reef was developed on an erosional surface when sea level was lower. Purdy (1974a, 1974b) suggested that a peripheral rim may have developed along the shelf edge during periods of subaerial erosion. The valley bathymetry between the ridges is discontinuous and has channels that cut across the outer ridge. This strongly suggests that erosional drainage processes were active during the development of the karst surface and that resulting landforms were subsequently enlarged by reef growth after submergence.
The width of the Guanica shelf (fig. 2) is only 3 to $4 \mathrm{~km}$, and water depths average $12 \mathrm{~m}$. With the exception of the Guánica submarine canyon, the shelf relief here is more uniform than on the Parguera shelf, and there is no separate middle shelf area.

The shallow inner shelf between Punta Jorobado and Punta Brea is narrow and exposed to erosion by the sea, but the inner shelf between Punta Brea and Cayos de Caña Gorda is more protected. A line of emergent and submerged reefs separates the inner and outer shelf and acts as a baffle, producing an area of lower wave energy and, hence, increased and finer grain sized deposition on this part of the inner shelf, and there is no separate middle shelf area.

The Bahía de Guánica estuary is an extension of the GuayanillaGuánica submarine canyon (Trumbull and Garrison, 1973). It is a deep, narrow bay that is bounded by hills on its east and west. The submarine canyon extends southeast across the insular slope. The canyon has been filled with sediments between the mouth of the bay and Corona La Laja reef. From the reef to the shelf edge, the canyon is 25 to $35 \mathrm{~m}$ deep.

\section{SEDIMENTS}

Holocene deposits form a thin veneer over the late Pleistocene erosional surface. The shape and development of both the reef and the unconsolidated deposits have been strongly influenced by the morphology of this erosional surface, as well as by the duration of inundation, the availability of sediment, and the energy of the environment.

Grain sizes of the unconsolidated sediments can be divided into six groups. They are sand, silty sand, sandy silt, clayey silt, silty clay, and a mixed sediment class (fig. 3). More than two-thirds of the shelf is covered with sand-sized sediment or is bedrock with only pockets of thin sand deposition. The distribution and relative abundance of the textural groups are shown in figure 4 .

Silty sand forms the second most abundant size category. Silty sand is found on the middle and inner shelf at Parguera and on the outer and eastern part of Montalva and Guánica bays. Sediments of mixed grain size occur on the middle shelf around Cayo Enrique and westward toward Arrecife San Cristobal. Mixed grain size sediments are also found in Bahía Montalva, in the inner mangrove lagoons at Parguera, and in isolated patches in Bahía de Guánica.

Sandy silts were found in Bahía Montalva and on the inner shelf near Guánica and Caña Gorda. The clayey silt facies is primarily in Guánica and Montalva bays, although an area of fine-grained carbonate deposition occurs behind Arrecife Enmedio on the Parguera shelf. Except for isolated occurrences, the silty clay facies is limited to Bahía de Guánica, Bahía Fosforescénte, and the inner mangrove channel near Parguera.

Total organic carbon in the sediment was measured in two previous studies by Sawyer (1980) from samples taken along a line from Bahía Fosforescénte to the shelf edge and by Zapata (1982) from samples taken along a line from the mangrove lagoon at $\mathrm{La}$ Parguera to south of Cayo Enrique (fig. 5). The highest values (4 to 5 percent organic carbon by weight) were reported in the inner mangrove lagoon and Bahía Fosforescénte. The values for the inner shelf samples ranged from 1.0 to 2.8 percent organic carbon. The outer shelf samples had values of only 0.3 to 0.9 percent). The data show little correlation with grain size. The highest organiccarbon content from the lagoon at Parguera and Bahía Fosforescénte probably reflects both source materials and a lower energy environment in more protected waters. 


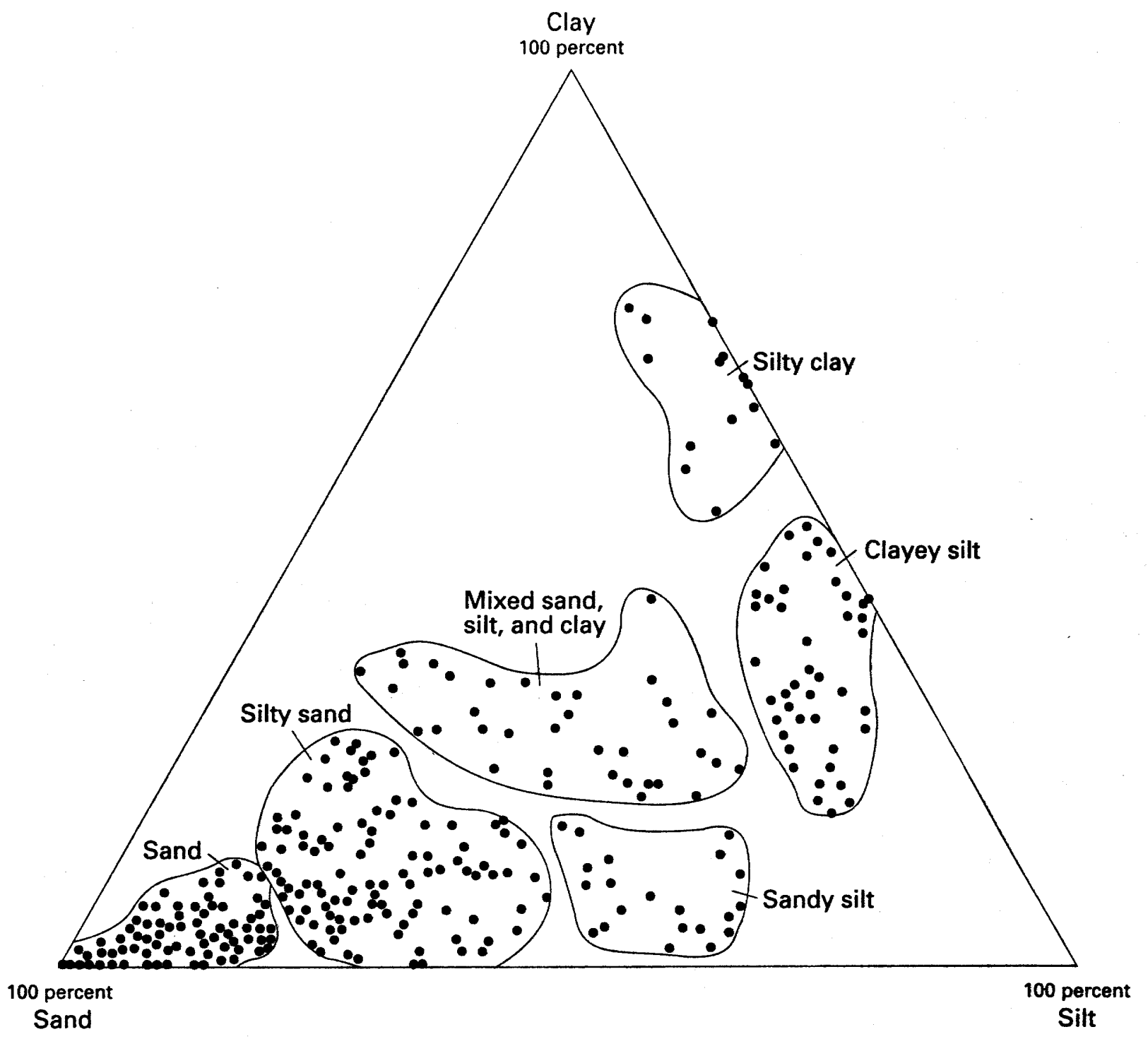

Figure 3.-Grain size diagram of surficial shelf sediments, Parguera-Guánica area, Puerto Rico. Dots represent samples from figure 4.

Sediments in much of the mapped area are more than 90 percent biogenic calcium carbonate (fig. 6) due to the deposition of marine organisms. More protected nearshore areas, particularly those areas which receive more drainage from the land, have more terrigenous sediment and less biogenic calcium carbonate.

The Río Loco is the only permanent drainage system bringing terrigenous sediment to the Parguera-Guánica area. During periods of heavy rain, such as the typical 36 - to 48 -hour periods of 20 to $50-\mathrm{cm}$ rainfall that are associated with hurricanes, terrigenous silts and clays are transported into the nearshore area by local runoff. From there, currents carry the material westward.

Some terrigenous material is transported through the shoreline mangrove to the mangrove channels and inner shelf where it mixes with fine-grained carbonate sediments. The mangrove serves as a retarding baffle that traps most of the terrigenous sediment and prevents its transport into areas of reef deposition.

Except for local variations, the sediment types are consistent from the Punta Cabo Rojo area to the west (Grove and Trumbull, 1978), through Bahía de Guayanilla (Morelock and others, 1980), and eastward to Ponce (Acevedo and others, 1989; Beach and Trumbull, 1981). Sedimentary facies have been distinguished as consolidated or unconsolidated. The unconsolidated sediments are differentiated by grain size, by percent calcium carbonate, and by constituent skeletal material in the carbonate sand fraction. (See specifics in fig. 12, and distribution in fig. 7).

Living coral reefs that reach the surface, submerged reefs that crest below $4 \mathrm{~m}$, and hardground areas form the major units of consolidated carbonate deposition (fig. 7). Pockets of sand do occur in these environments, but they are too small to map at this scale.

Actively growing reefs were mapped as coral reef where the reef crest is at or near sea level and the fore-reef zone is developed. These reefs have a sandy back-reef facies, patch reefs, and sparse cover of Thalassia. Reefs that are below $4 \mathrm{~m}$ of water depth, that have no crest, and that generally do not have an Acropora palmata zone were mapped as submerged reef.

Areas of consolidated hard-rock bottom materials that have less than 8 percent living coral or scattered areas of patchy sand and 
coral were mapped $a^{3}$.hardground. Small patch reefs were included in these hardground areas because they were too small to map at this scale.

The outer shelf was mapped as predominantly outer-shelf sand or hardground. The insular shelf-to-slope break is marked by an almost continuous line of submerged coral reefs that rise from a base level of 22 to $25 \mathrm{~m}$ to 16 to $18 \mathrm{~m}$.

Unconsolidated sediments were mapped by grain size and percent calcium carbonate, and the sand was classified according to biogenic constituents. (Ginsburg, 1956; Swinchatt, 1964; Lidz and others, 1985).

The reef skeletal sands are restricted to reef aprons shoreward of the reef crest. These sands are distinguished by increased amounts of coral fragments in comparison with other sands. Transport of coral fragments in such abundance is known to be very limited (Morelock and Koenig, 1967; Saunders, 1973), and, therefore, they must be of local origin.

The nearshore Halimeda facies (Saunders, 1973) consists of sand to silty sand. Fragments of Halimeda sp. are dominant, although mollusk fragments are common.

The carbonate mud facies is restricted to the shelf shoreward of Enrique, Media Luna, Enmedio, and Romero reefs in the quiet water zone. Carbonate mud (the result of local biogenic production and erosion) is produced and deposited in this area of reduced wave energy. The sand-sized constituents of this mud facies differ in abundance from those of the three carbonate sands in that mollusk fragments dominate.

The outer shelf sands are a mixture of stained relict salt-andpepper sands, gravelly sands, and modern biogenic sands composed of molluskan fragments, benthic foraminifers, and spicules. The outer shelf sands have much fewer Halimeda sp. compared to the other sand facies.

In general, mixed carbonate and terrigenous sediments are restricted to the nearshore areas at Parguera, and at Fosforescénte, Montalva, and Guánica bays. The amount of terrigenous material on the shelf is related to source and mode of transportation; most of the coarser terrigenous sediments in a mixed environment may be relict (Morelock and Koenig, 1967). Most of the terrigenous component on the nearshore shelf at Parguera are clays and silts that have been introduced into the modern environment by wind transport or sheet runoff during floods.

The carbonate sand and terrigenous mud facies was mapped in only a few areas, and probably results from low production of carbonate material. The carbonate and terrigenous mud facies fills much of Bahía Fosforescénte and the inner mangrove channels at La Parguera. Their distribution marks the outer limit of appreciable transport of terrigenous silt and clay. The terrigenous mud facies is also very limited in areal extent. Here, more than 70 percent terrigenous clay and silt are accumulating in low-energy environments with limited export.

The pattern of Holocene sediment thickness is complex. Much of the Parguera shelf is blanketed by 4 to $6 \mathrm{~m}$ of carbonate sand and 6 to $15 \mathrm{~m}$ of consolidated carbonate sediment, but less than $4 \mathrm{~m}$ of Holocene deposits occur in the Guánica shelf except for the Guánica submarine canyon (fig. 8).

Greater thickness in the Parguera shelf area appears to be mainly reef growth over erosional highs. Maximum sediment accumulation is a combination of reef-wall growth, reef talus, and thick accumulations of carbonate sand landward of the reef structure. On the open shelf, unconsolidated sand thicknesses vary considerably, and the pattern of accumulation shows no apparent trend.
Cayo Turromote and the Turromote ridge are marked by a pattern of increased sediment thickness that represents Holocene reef growth. Contours of the late Pleistocene erosional surface (fig. 9) reveal bathymetric highs beneath the Turromote and Margarita reefs, but amplitudes are less than that of the present-day bathymetry.

\section{SEISMIC LINES}

Seismic-reflection profiles (figs. 10 and 11) were obtained in 1.980 using an Uniboom source and a multi-element hydrophone. Navigation during the survey was provided by radar ranging for offshore lines and by sextant 3-point solutions for the nearshore lines. For interpretation of thickness, sound velocity in the unconsolidated sediments was assumed to be the same as in water $(1500$ meters per second). All Holocene sediments were deposited on an erosional hardground surface. The seismic profiles should be compared with figs. 7,8 , and 12 .

Parguera line 14 crosses the western submerged crest of Arrecife Margarita. The reef is built over an erosional surface that has 2 to $3 \mathrm{~m}$ of local relief. Reef growth is 4 to $5 \mathrm{~m}$ in total, thickening seaward. The rough erosional surface on the inland side of Arrecife Margarita has been filled with more than $3 \mathrm{~m}$ of unconsolidated sands, which extend westward into the area described by Grove and Trumbull (1978). An expanse of Holocene sand 2 to $3 \mathrm{~m}$ thick and hardground lies seaward of Arrecife Margarita. The shelf-edge reef may have grown over an erosional rim, but the contact between older limestone and the reef cannot be determined from the seismic profile.

Line 6 provides an east-west profile through the middle-shelf region. The erosional surface is relatively smooth in the west, although sediments of irregular thickness overlie it. The underlying sediment appears to have sound velocities close to those of seawater; there is no evidence of structural highs beneath the Holocene carbonaceous sand and silt. To the east, sediments thin as the erosional surface gradually becomes more shallow and irregular.

Line 12 begins landward of Arrecife Ahogada and continues seaward toward the shelf edge, transecting a number of reefs. The reefs over the 9-m terrace surface are generally 4 to $5 \mathrm{~m}$ thick, and 2 to $4 \mathrm{~m}$ of unconsolidated sediment have accumulated shoreward of each reef. Three to six $m$ of sand lie over the middle shelf, but sand accumulates in thicknesses as much as 6 to $8 \mathrm{~m}$ on the outer shelf. The double reef ridge along the shelf edge is apparent; however, the amount of coral growth and the elevation of a possible karst rim cannot be determined from the seismic profile. The general morphology associated with these ridges suggests a complex history. The troughs in and between the reefs originally may have been drainage channels that first ran parallel to the rim escarpment of a single reef system, and then out to the slope. The troughs created a series of discontinuous depressions in the margin reef and, eventually, a double-reef system that has been accentuated by subsequent Holocene reef growth.

Line 9 extends from the forereef of Arrecife Enmedio, across the submerged eastern part of Turromote reef, and to a submerged reef south of Arrecife Turromote. About $6 \mathrm{~m}$ of sediment lies between the Enmedio and Turromote reefs, and 8 to $12 \mathrm{~m}$ of reef growth overlies the erosional surface. The presence of a large sinkhole in the underlying limestone supports the concept of karst erosion of the limestone during lower sea level.

Line 11 runs south from Punta Jorobado to the shelf edge. The line is near the onshore contact between the Cretaceous and 
Tertiary limestones that were exposed during the late Pleistocene erosion, and the line coincides with the difference between the Parguera and Guánica shelves. This profile shows a relatively smooth surface seaward, but the shoreward underlying limestone appears more deeply eroded. A small depression is seen landward of the shelf-edge reef, but there is no second, inner reef ridge like the one along the shelf-edge area farther west. About 6 to $8 \mathrm{~m}$ of sand has accumulated over the middle shelf area, and this sandy fill has reduced the overall relief of the erosional surface profiled on this line. Reef growth on the shelf margin appears to be only 2 to $3 \mathrm{~m}$ thick.

Line 72 runs from Bahía de Guánica to the shelf edge; it crosses the sediment-filled valley of the Guanica submarine canyon, then 1 to $3 \mathrm{~m}$ of hardground and sediment on the outer shelf. The canyon bottom is about $24 \mathrm{~m}$ below present sea level; it contains up to $12 \mathrm{~m}$ of sediment. This deposit was not cored, but the bedding suggests that part of the fill is fluvial sand. The underlying bedrock shows several previously filled channels that were part of the Guánica canyon system. The double ridge crossed on the outer shelf margin is difficult to interpret on this profile, but a short line shot $1 \mathrm{~km}$ to the east shows less than $1 \mathrm{~m}$ of reef buildup over the late Pleistocene erosional surface.

From the seismic data, it is clear that Holocene deposits (fig. 8) form a thin veneer over the late Pleistocene erosional surface (fig. 9). The shape and development of the reefs and the deposition of unconsolidated sediments have been strongly influenced by the morphology of the surface, the duration of inundation, the availability of sediments, and the energy of the environment. (The complexities of sedimentation were discussed along with figure 7.) The variation in the amount of relief under the reefs and that many of the reefs have grown upward from an almost flat terrain suggest that the reef thickness is actual constructional relief, and not an artifact of higher acoustic velocities.

\section{SUMMARY}

The southwestern shelf of Puerto Rico is underlain by Cretaceous, Tertiary, and Pleistocene limestones that can be traced on the seismic records to nearby exposed subaerial outcrops. These limestones are overlain by Holocene reefs and sediments. The surface of the limestone platform and the pattern of unconsolidated sedimentation have resulted from the erosion and deposition of the last glacial sea-level lowstand and the post-glacial sea-level rise. The entire shelf and upper slope were exposed to subaerial erosion from before 15,000 years until after 10,000 years ago, resulting in a karst topography similar to that of Honduras (Purdy, 1974a, 1974b). The erosional surface gradually deepens westward from $20 \mathrm{~m}$ below present sea level south of Punta Jorobado to $40 \mathrm{~m}$ below sea level at the southwestern edge of the study area. The marked difference in the surface morphologies of the Parguera and Guánica shelves is reflected on figure 2. Bathymetry of the late Pleistocene surface (fig. 9) is less complex than the modern surface (fig. 2). The modern surface reflects the differential growth of Holocene reefs, sea-level rise, and variations in sediment deposition. The shelf edge, as observed during diving surveys, has karst sink holes and slump blocks, and it is outlined by a submerged shelf-edge reef that is double in some places.

The Guánica shelf is much shallower than the Parguera shelf and may have been emergent longer, which explains why there is less modification by reef growth and sedimentation of the Guánica shelf. The narrowness of the shelf and higher wave energies over it have kept the modern bathymetry simple. The Guánica canyon cuts more than $40 \mathrm{~m}$ into the shelf edge, but shoals to $12 \mathrm{~m}$ at the entrance to Bahía de Guánica. The canyon has a smooth gradient from the shelf edge, through the bay, and to the mouth of the Río Loco. On the shelf and in Bahía de Guánica, part of the canyon is buried by modern sediments. The canyon appears to have existed as a continuation of the Río Loco during emergence.

\section{ACKNOWLEDGEMENT}

Although this study was done by the U.S. Geological Survey in cooperation with the Puerto Rico Department of Natural Resources, authors Morelock and Goenaga were at the University of Puerto Rico at Mayagüez. Students of the Department of Marine Sciences, University of Puerto Rico at Mayaguiez, helped collect and analyze some of the unpublished oceanographic data summarized herein. Samples for grain size and percent of acid-insoluble residue were analyzed at the Puerto Rico Department of Natural Resources laboratory at San Juan.

\section{REFERENCES CITED}

Acevedo, Roberto, Morelock, Jack, and Olivieri, R.A., 1989 , Modification of coral reef zonation by terrigenous sediment stress: Palaios, v. 4 , no. 1 , p. 92-100.

Almy, C.C., Jr., 1965, Parguera Limestone, Upper Cretaceous Mayagüez Group, southwest Puerto Rico: Houston, Tex., Rice University, unpublished Ph.D. thesis, 203 p.

Almy, C.C., Jr., and Carrion-Torres, Carlos, 1963, Shallow-water stony corals of Puerto Rico: Caribbean Journal of Science, $v$. 3, no. 2-3, p. 133-162.

Armstrong, R.A., 1981, Changes in Cayo Enrique, La Parguera, Puerto Rico, from 1936 to 1980 using aerial photoanalysis: Mayagüez, University of Puerto Rico, unpublished Master's thesis, $74 \mathrm{p}$.

Beach, D.K., 1975, Sedimentation on the western Isla Caja de Muertos insular shelf, Puerto Rico: Mayagüez, University of Puerto Rico, unpublished Master's thesis, $100 \mathrm{p}$.

Beach, D.K., and Trumbull, J.V.A., 1981, Marine geologic map of the Puerto Rico insular shelf, Isla Caja de Muertos area: U.S. Geological Survey Miscellaneous Investigations Series Map, I-1265, scale 1:40,000.

Boulon, R.H., Jr., 1980, Patterns of coral community structure and species diversity of a submerged shelf-edge reef off southwestern Puerto Rico: Mayagüez, University of Puerto Rico, unpublished Master's thesis, $61 \mathrm{p}$.

Del Valle, M.A., 1981, Aspects on the composition, occurrence, and distribution of the benthic marine macroalgae in Bahía de Guánica, Puerto Rico: Mayagüez, University of Puerto Rico, unpublished Master's thesis, $117 \mathrm{p}$.

Ginsburg, R.N., 1956, Environmental relationships of grain size and constituent particles in some South Florida carbonate sediments: American Association of Petroleum Geologists Bulletin, v. 40 , no. 10 , p. 2384-2427

Glynn, P.W., 1973, Ecology of a Caribbean coral reef: the Porites reef flat biotope: Part I, Meteorology and Hydrography: Marine Geology, v. 20, p. 297-318.

Grossman, I.G., 1963, Geology of the Guánica-Guayanilla Bay area, southwestern Puerto Rico, in Geological Survey Research 1963: U.S. Geological Survey Professional Paper 475-B, p. B114-B116. 
Grove, K.A., and Trumpull, J.V.A., 1978, Surficial geologic maps and data on three potential offshore sand sources on the insular shelf of Puerto Rico: U.S. Geological Survey Miscellaneous Field Studies Map MF-1017.

Lidz, B.H., Robbin, D.M., and Shinn, E.A., 1985, Holocene carbonate sedimentary petrology and facies accumulation, Looe Key National Marine Sanctuary, Florida: Bulletin of Marine Sciences, v. 36 , no. 3, p. 672-700.

Macintyre, I.G., 1972, Submerged reefs of eastern Caribbean: American Association of Petroleum Geologists Bulletin, v. 56, no. 4 , p. $720-738$.

Matta, J.L., 1981, The effects of Hurricane David on the benthic macroalgae of a coral reef in La Parguera, Puerto Rico: Mayagüez, University of Puerto Rico, unpublished Master's thesis, $130 \mathrm{p}$.

Morelock, Jack, Boulon, Kimberly, and Galler, Gabriel, 1979, Sediment stress and coral reefs, in Lopez, J.M., ed., Proceedings of Symposium on Energy Industry and the Marine Environment: Mayagüez, University of Puerto Rico, Guayanilla Bay Center for Energy and Environmental Research, p. 46-58.

Morelock, Jack, Grove, K.A., and Trumbull, J.V.A., 1980, Sediments and Recent geological history of the Guayanilla submarine canyon system, Puerto Rico: Caribbean Geological Conference, 9th, Santo Domingo, Dominican Republic, August 16-20, 1980, Transactions, v. 1, no. 1, p. 129-138.

Morelock, Jack, and Hernandez, M.L., 1982, Physical and geological parameters in Puerto Rican estuaries: Project report to Water Resources Institute: Mayagüez, University of Puerto Rico, 45 p.

Morelock, Jack, and Koenig, K.J., 1967, Terrigenous sedimentation in a shallow water coral reef environment: Journal of Sedimentary Petrology, v. 37, no. 4, p. 1001-1005.

Morelock, Jack, and Mathews, Scott, 1982, Bioturbation of carbonate reef sands: National Geographic Society Research Reports, v. 14 , p. $479-486$.

Morelock, Jack, Schneidermann, Nahum, and Bryant, W.R., 1977, Shelf reefs, southwestern Puerto Rico, in Frost, S.H., Weiss, M.P., and Saunders, J.B., eds., Reefs and related carbonates; ecology and sedimentology: American Association of Petroleum Geologists Studies in Geology, 7th Caribbean Geological Conference, Guadeloupe, French Antilles, July 1-2, 1974 , no. 4 , p. 17-25.
Purdy, E.G., 1974a, Karst-determined facies patterns in British Honduras: Holocene carbonate sedimentation model, in Comparative sedimentology of carbonates symposium: American Association of Petroleum Geologists Bulletin, v. 58, no. 5, p. 825-855.

Purdy, E.G., 1974b, Reef configurations, cause and effect, in Laporte, L.F., ed., Reefs in time and space; selected examples from the Recent and Ancient: Society of Economic Paleontologists and Mineralogists, Special Publication No. 18, p. 9-76.

Quinn, A.A., 1972, A study of an area of the insular shelf of southwest Puerto Rico: a buttressed groove and spur formation: Brooklyn, New York, Long Island University, unpublished Master's thesis, $51 \mathrm{p}$.

Rogers, C.S., 1977, The response of a coral reef to sedimentation: Gainesville, University of Florida, unpublished Ph.D. thesis, $210 \mathrm{p}$.

Saunders, C.E., 1973, Carbonate sedimentation on the inner shelf, Isla Magueyes, Puerto Rico: Mayagüez, University of Puerto Rico, unpublished Master's thesis, $77 \mathrm{p}$.

Sawyer, K.C., III, 1980, Preservational pattems of organic material in a carbonate shelf environment, southwest Puerto Rico: Norman, Okla., University of Oklahoma, unpublished Master's thesis, $161 \mathrm{p}$.

Schneidermann, Nahum, Pilkey, O.H., and Saunders, C.E., 1976, Sedimentation on the Puerto Rico insular shelf: Journal of Sedimentary Petrology, v. 46, no. 1, p. 167-173.

Swinchatt, J.P., 1965, Significance of constituent composition, texture, and skeletal breakdown in some Recent carbonate sediments: Journal of Sedimentary Petrology, v. 35, no. 1, p. 71-90.

Trumbull, J.V.A., preparer, 1981, Oceanographic data off Puerto Rico and the Virgin Islands: Berkeley, University of Calif., Lawrence Berkeley Laboratory Publication 360, 1 sheet.

Trumbull, J.V.A., and Garrison, L.E., 1973, Geology of a system of submarine canyons south of Puerto Rico: U.S. Geological Survey Journal of Research, v. 1, no. 3, p. 293-299.

Volckmann, R.P., 1984, Geologic map of the Cabo Rojo and Parguera quadrangles, southwest Puerto Rico: U.S. Geological Survey Miscellaneous Investigations Series Map 1-1557, scale 1:20,000.

Zapata, Gerardo, 1982, Organic content of selected samples at La Parguera quadrangle: Mayagüez, University of Puerto Rico, unpublished class report, $8 \mathrm{p}$. 

